\title{
Alternative career pathways for international medical graduates towards job market integration: a literature review
}

\author{
Tanvir C. Turin ${ }^{1}$, Nashit Chowdhury ${ }^{1}$, Mark Ekpekurede², Deidre Lake², Mohammad Ali Ashraf \\ Lasker'2, Mary O'Brien³, Suzanne Goopy ${ }^{4}$
}

${ }^{1}$ Department of Family Medicine, Department of Community Health Sciences, Cumming School of Medicine, University of Calgary, Calgary, AB, Canada

${ }^{2}$ Alberta International Medical Graduates Association, Calgary, AB, Canada

${ }^{3}$ School of Languages, Linguistics, Literatures and Culture, University of Calgary, Calgary, AB, Canada

${ }^{4}$ Faculty of Nursing, University of Calgary, Calgary, AB, Canada

Correspondence: Tanvir C. Turin, Department of Family Medicine, Cumming School of Medicine, University of Calgary, G012F, Health Sciences Centre, 3330 Hospital Drive NW, Calgary, Alberta, Canada, T2N 4N1. Email: turin.chowdhury@ucalgary.ca

Accepted: April 05, 2021

\begin{abstract}
Objectives: To inform the current level of research about alternative career pathways for international medical graduates and synthesize knowledge of the barriers, facilitators and potential outcomes of alternative career pathways for international medical graduates.

Methods: We searched MEDLINE, EMBASE, Scopus, and Google Scholar for relevant publications to February 2020. From 809 articles, after two levels of screening, 23 articles were selected. We conducted thematic content analysis and reported the findings of the study following the Preferred Reporting Items for Systematic Reviews and Meta-Analyses Extension for Scoping Reviews guidelines.

Results: All 23 articles reported on alternative careers for international medical graduates in either the United States or Canada. A variety of study methods were noted, including original research, scoping reviews, reports for organizations, and commentaries. Studies incorporated a variety of methods, including surveys, focus groups, interviews, analysis of
\end{abstract}

administrative documents, and program evaluation. Many potential benefits of alternative careers were reported for both international medical graduates and stakeholders. Barriers to pursuing alternative careers included both individual- and systemic-level barriers. Facilitators included skillbuilding workshops, targeted bridging programs, connecting with employers, supporting organizations, and international medical graduates.

Conclusions: The scarce literature on alternative career pathways indicates that this research is beneficial for both international medical graduates and their host countries. Initiating capacity building programs for alternative career pathways for international medical graduates might be a worthy investment for host countries, especially in underserved areas. Pilot initiatives incorporating bridging programs for international medical graduates are recommended.

Keywords: Immigrants, alternative career pathways, transferable skills, international medical graduates, integration

\section{Introduction}

In this era of global migration, developed countries admit a substantial number of new immigrants every year through their immigration and refugee policies. ${ }^{1}$ These immigrant or newcomer populations come from a number of ethno-geographic backgrounds and exhibit differences in their sociocultural and life practices that influence their settlement needs, including social care, education, health, and access to

the labour market. ${ }^{2-4}$ Internationally trained medical professionals, also known as international medical graduates $(\mathrm{IMGs})^{5}$ are a highly skilled but struggling segment of the immigrant population. IMGs are graduates of medical schools located outside the country where they intend to integrate professionally. ${ }^{6,7}$ They are also referred to as foreign medical graduates (FMGs), overseas trained graduates (OTGs), 
internationally trained physicians (ITPs), or internationally educated physicians (IEPs). ${ }^{7}$

The natural career course of these skilled professionals is to become a practicing physician; however, according to a Canadian report, as few as $6 \%$ of them will succeed in becoming a licenced physician. ${ }^{8}$ This extremely low rate of success is mostly attributable to systemic barriers, including the limited number of residency spots (a requirement for licencing) and discrimination against IMGs, as well as individual barriers such as socio-cultural and linguistic differences. ${ }^{5,9}$ Failing to integrate professionally as a practicing physician, many IMGs waste their skills by performing survival jobs ${ }^{10}$ completely unrelated to their educational background. In doing so, these highly skilled immigrant health professionals have become a symbol of the deskilling of highly skilled migrants in Canada. ${ }^{11}$

Against this backdrop, alternative careers, those jobs where IMGs' health-related knowledge, skills, and experience can be used, have emerged as a way to facilitate better professional integration for IMGs. ${ }^{12}$ However, during our preliminary exploration of the literature, we noticed the scarcity of literature in this area. Further, limited information is available regarding the potential outcomes of alternative career pathways (ACPs) for IMGs, the challenges they face, and how to facilitate their pursuit of alternative career options. Moreover, studies indicate there is a lack of awareness among IMGs and other stakeholders, such as potential employers of alternative jobs, the health- and wellness-related medical education sector, the immigrant-serving public, and private and non-profit bodies regarding alternative careers as a potential pathway to the professional integration of IMGs into the Canadian labor market. ${ }^{12}$

Through this rapid scoping review, we plan to explore the current level of international research regarding ACPs for IMGs and to synthesize the knowledge of the barriers and facilitators and potential outcomes of pursuing ACPs for IMGs. This understanding will help us determine and undertake the next steps in working on this important but overlooked issue.

\section{Methods}

\section{Rapid review}

In general, a rapid review is a form of review that synthesizes knowledge within a brief period, in which stages of a fullblown traditional review, such as a systematic scoping review, are simplified/fast-tracked and/or skipped to generate a quick outcome. ${ }^{13} \mathrm{~A}$ rapid review approach is usually selected for new or emerging research topics and updates of previous reviews and to quickly generate an outline of the evidence-based knowledge of a policy or practice for decisionmakers. As professional integration of IMGs through ACPs is a relatively new and emerging topic of interest, and a quick overview of the relevant knowledge in the literature may help direct appropriate next steps, we adopted a rapid scoping review approach for this study.

Unlike standard systematic or scoping reviews, there is no established framework to follow in conducting a rapid review. Many studies have followed their own strategies or modified or adapted various proposed frameworks to meet their specific research goals. ${ }^{14,15} \mathrm{We}$ conducted our rapid review by following a simplified framework for scoping reviews as employed by few other studies. ${ }^{14-16}$ All the stages of the scoping review were followed but a limited number of databases were used. As a Preferred Reporting Items for Systematic Reviews and Meta-Analyses (PRISMA) framework has not been developed for rapid scoping reviews, we followed the PRISMA-Extension for Scoping Reviews (PRISMA-ScR) checklist and guidelines (please see Appendix 1). ${ }^{17}$

\section{Stage 1: Identifying the research question}

Identifying a clear and appropriate research question that limits the focus on the literature within a specific area of interest without excluding possible outcome variables is the first step of a scoping review. For this rapid scoping review, we identified the following research questions:

1. What research has been undertaken regarding the professional integration of IMGs through ACPs?

2. What are the benefits to IMGs and stakeholders of integrating into ACPs?

3. What are the barriers and facilitators faced by IMGs when opting to pursue ACPs?

\section{Stage 2: Identifying relevant studies}

\section{Published literature}

As a limited number of databases are used to extract information for a rapid review, the databases need to be most representative of the topic of the research question and field. ${ }^{14}$ After thorough consideration and discussion among the members of the research team, the three most appropriate academic databases were selected for this review. As the subject of IMGs is primarily related to healthcare, we selected MEDLINE (Ovid) and EMBASE. However, as professional integration often involves multiple disciplines, including social sciences, migration, human geography, and education, we included Scopus to capture those particular aspects of IMGs' integration to ACPs. We developed the search terms, and these terms were further reviewed and validated by an experienced librarian. A complete list of search terms is provided in Table 1. In addition, we also conducted single citation searches and used a pearl growing approach or citation mining by reviewing the reference lists of all selected papers and publications and included additional studies that fulfilled our inclusion criteria (Appendix 2 shows the search strategy for MEDLINE and EMBASE). 


\section{Grey literature}

To obtain information from unpublished or in-progress studies, we also searched the grey literature. Extracting publicly available information on ACPs for IMGs was also incorporated into the grey literature search. We selected Google Scholar for our search, as it is one of the most commonly used grey literature sources, and studies indexed in other databases are often accessible through Google Scholar. ${ }^{18,19}$ Moreover, Google Scholar is a useful search engine to identify the organizational repositories and relevant information on websites of key national, international, professional, immigrant-serving, community, and government and non-government organizations. Search terms are listed in Table 1.

Table 1. Search terms

IMG [MEDLINE and Embase]
International adj2 medical adj2 graduate* OR Foreign Medical Gradu-
ates [MeSH] OR foreign adj2 medical adj2 graduate* OR internationally
adj2 trained adj2 doctor* OR internationally adj2 trained adj2 physician*
OR internationally adj2 trained adj2 medical graduate* OR internation-
ally adj2 educated adj2 physician* OR internationally adj2 trained adj2
health professional OR internationally adj2 educated adj2 health profes-
sional OR foreign adj2 trained adj2 doctor* OR foreign adj2 trained adj2
physician* OR foreign adj2 trained adj2 medical graduate* OR foreign
adj2 educated adj2 physician* OR foreign adj2 educated adj2 health
professional OR overseas adj2 trained adj2 doctor*

Career [MEDLINE and Embase]

(Career Choice [MeSH] OR profession* adj3 integrat* OR alternative adj3 career OR integrat ${ }^{*}$ )

\begin{abstract}
For Scopus
(International medical graduate*) OR (foreign medical graduate*) OR (internationally trained doctor $^{\star}$ ) OR (internationally trained physician ${ }^{*}$ ) OR (internationally trained medical graduate*) OR (internationally educated physician*) OR (internationally trained health professional) OR (internationally educated health professional) OR (foreign trained doc-

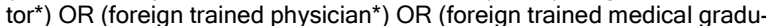
ate $^{\star}$ ) OR (foreign educated physician ${ }^{\star}$ ) OR (foreign educated health professional) OR (overseas trained doctor ${ }^{*}$ )

AND

(Career Choice OR profession* integrat* OR alternative career OR integrat $\left.^{*}\right)$
\end{abstract}

\section{For Google Scholar}

((International medical graduate) OR (foreign medical graduate) OR (internationally trained doctor) OR (internationally trained physician) OR (internationally trained health professional) OR (internationally educated health professional) OR (overseas trained doctor))

AND

(career OR profession OR integration)

\section{Stage 3: Study selection}

To extract the relevant studies on professional integration of IMGs through ACPs we used specific definitions of terms and appropriate databases to ensure sufficient and relevant coverage. We followed the PICOS structure (Table 2) in selecting studies for this review. We did not restrict studies based on country of origin or date of publication, but we excluded all studies focusing on residency-related issues of IMGs. We included studies published in the English language only.
All search outcomes were assessed through a two-step screening process: (i) title-abstract review, and (ii) full-text review (Figure 1). Following common rapid review strategies, ${ }^{14}$ only one researcher conducted the screening. In the first screening step, the reviewer screened the papers based on the relevance of their titles and abstracts to our research questions. The full texts of the eligible abstracts were obtained and scrutinized for inclusion in the rapid review based on their relevance to alternative careers for IMGs. If the primary reviewer could not decide whether or not to include an article, other members of the research team reviewed it to achieve consensus.

Table 2. Inclusion and exclusion criteria

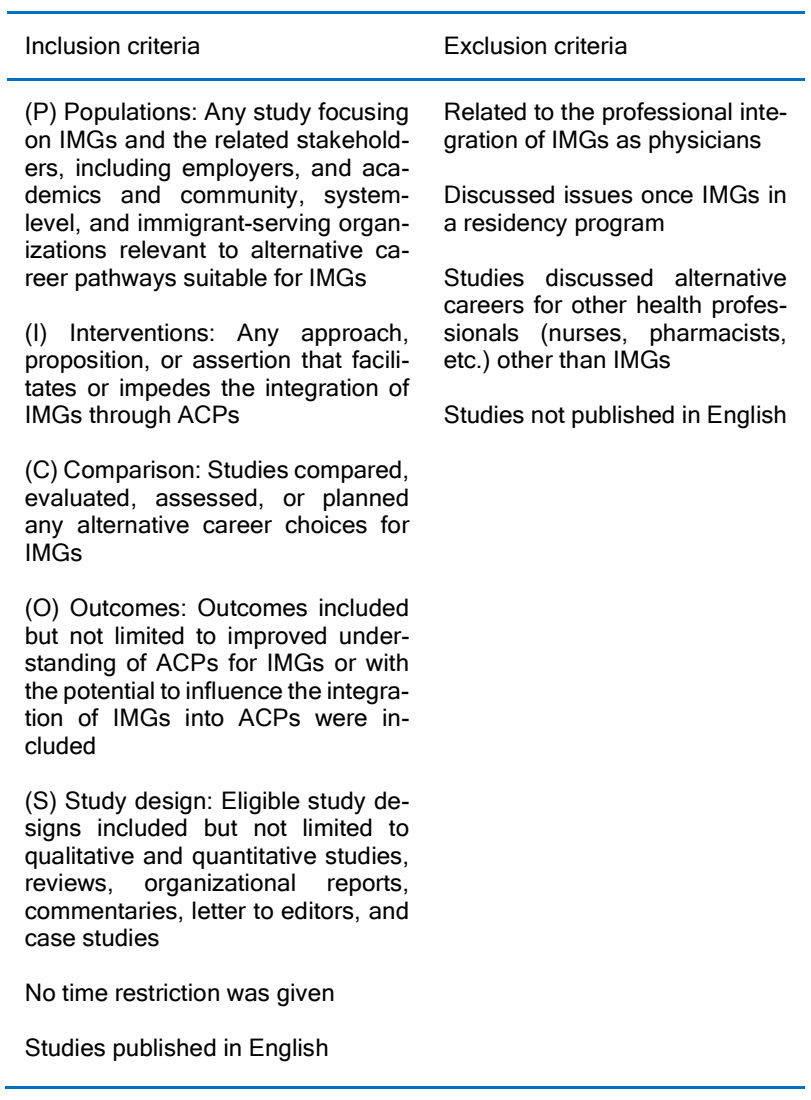

Note: $\mathrm{ACP}=$ alternative career pathway; IMG = international medical graduate .

\section{Stage 4: Charting the data}

Data charting involved reading the full text of the eligible articles and identifying the key characteristics of those studies and their outcomes. The research team reviewer charted the information in a limited and predetermined data charting form. Study characteristics were extracted, including citation, study location, study type, study method, and study sample (Table 3). Further data on ACPs, barriers, facilitators, benefits of an alternative career choice, and take-away points were charted using emergent thematic coding (Table 4). EndNote (Clarivate Analytics, Philadelphia, Pennsylvania, USA) and Microsoft Excel (Microsoft Corporation, Redmond, Washington, USA) were used for data charting. 
Turin et al. - Alternative career pathways for international medical graduates

Table 3. Study characteristics

\begin{tabular}{|c|c|c|c|c|c|}
\hline Study & Date & $\begin{array}{l}\text { Location } \\
\text { of study }\end{array}$ & Type of research & Methods & Sample/size \\
\hline $\begin{array}{l}\text { Alberta } \\
\text { International } \\
\text { Medical } \\
\text { Graduate } \\
\text { Association }{ }^{27}\end{array}$ & 2019 & Canada & Report & Workshops followed by surveys & $\begin{array}{l}22 \text { IMGs who attempted to become licensed for three or } \\
\text { more years and had failed were either unemployed or un- } \\
\text { deremployed (i.e., working in a medical clinic or elsewhere } \\
\text { and making }<\$ 20 / h) \text {. Also, IMGs who were not interested } \\
\text { in pursuing licensure or seeking an alternative career as a } \\
\text { short-term goal were included. }\end{array}$ \\
\hline $\begin{array}{l}\text { American } \\
\text { Academy of } \\
\text { Physician } \\
\text { Assistants }^{32} \\
\end{array}$ & 1993 & $\begin{array}{l}\text { Florida, } \\
\text { USA }\end{array}$ & Report & $\mathrm{N} / \mathrm{A}$ & $\mathrm{N} / \mathrm{A}$ \\
\hline $\begin{array}{l}\text { Anderson \& } \\
\text { Gilliss }^{41}\end{array}$ & 1998 & USA & Report & $\mathrm{N} / \mathrm{A}$ & N/A \\
\hline Bhimji ${ }^{31}$ & 2010 & $\begin{array}{l}\text { Alberta, } \\
\text { Canada }\end{array}$ & Commentary & $\mathrm{N} / \mathrm{A}$ & $\mathrm{N} / \mathrm{A}$ \\
\hline Bhuiyan $^{23}$ & & $\begin{array}{l}\text { Ontario, } \\
\text { Canada }\end{array}$ & $\begin{array}{l}\text { Mixed method } \\
\text { study }\end{array}$ & $\begin{array}{l}\text { Surveys, interviews, and literature } \\
\text { review and analysis of evaluation } \\
\text { reports }\end{array}$ & $\begin{array}{l}\text { A total of } 67 \text { in four cohort groups; } 25 \text { men and } 42 \text { women } \\
\text { from over } 24 \text { different countries }\end{array}$ \\
\hline $\begin{array}{l}\text { Blain, Fortin \& } \\
\text { Alvarez }{ }^{28}\end{array}$ & 2017 & $\begin{array}{l}\text { Canada } \\
\text { and } \\
\text { Quebec }\end{array}$ & Qualitative study & Semi-structured interviews & $\begin{array}{l}31 \text { IMGs who hold degrees from outside the USA and } \\
\text { Canada }\end{array}$ \\
\hline $\begin{array}{l}\text { Bourgeault, } \\
\text { Neiterman, } \\
\text { Lebrun, Viers \& } \\
\text { Winkup }{ }^{20} \\
\end{array}$ & 2010 & Canada & Report & Interviews and document analysis & $\begin{array}{l}176 \text { IEHPs from British Columbia, Manitoba, Ontario, and } \\
\text { Quebec, including IMGs (67), IEN (70), and ITM (39) }\end{array}$ \\
\hline Cawley ${ }^{37}$ & 1994 & $\begin{array}{l}\text { Maryland, } \\
\text { USA }\end{array}$ & Letter to editor & $\mathrm{N} / \mathrm{A}$ & $\mathrm{N} / \mathrm{A}$ \\
\hline
\end{tabular}

Covell,

Neiterman \& 2016 Canada Qualitative study Scoping review (Arksey \& O'Malley ${ }^{16}$ ) 407 literature sources

Bourgeault ${ }^{29}$

\begin{tabular}{|c|c|c|c|c|c|}
\hline Fasser \& Smith ${ }^{38}$ & 1992 & USA & Report & $\mathrm{N} / \mathrm{A}$ & $\mathrm{N} / \mathrm{A}$ \\
\hline $\begin{array}{l}\text { Flowers \& } \\
\text { Olenick }\end{array}$ & 2014 & $\begin{array}{l}\text { Florida, } \\
\text { USA }\end{array}$ & Report & $\mathrm{N} / \mathrm{A}$ & $\mathrm{N} / \mathrm{A}$ \\
\hline $\begin{array}{l}\text { Fowkes, Cawley, } \\
\text { Herlihy \& } \\
\text { Cuadrado }^{36}\end{array}$ & 1996 & US & Report & $\mathrm{N} / \mathrm{A}$ & $\mathrm{N} / \mathrm{A}$ \\
\hline $\begin{array}{l}\text { Grossman \& } \\
\text { Jorda }^{40}\end{array}$ & 2006 & $\begin{array}{l}\text { Florida, } \\
\text { USA }\end{array}$ & Report & $\mathrm{N} / \mathrm{A}$ & $\mathrm{N} / \mathrm{A}$ \\
\hline $\begin{array}{l}\text { Howard, Garman } \\
\& \text { McCann }{ }^{26}\end{array}$ & 1995 & USA & $\begin{array}{l}\text { Quantitative } \\
\text { study }\end{array}$ & $\begin{array}{l}\text { A case-control study through } \\
\text { objective evaluation measures } \\
\text { through } 3 \text { tests: Test Item Bank, } \\
\text { Objective Structured Clinical } \\
\text { Examination, and Clinical } \\
\text { Performance Examination }\end{array}$ & $\begin{array}{l}32 \text { unlicensed IMGs who had graduated between 2-35 } \\
\text { years earlier from medical schools in the Philippines, } \\
\text { China, India, Cambodia, Mexico, Central America, South } \\
\text { America, Poland, Hungary, or the Soviet Union; } 6 \text { recent } \\
\text { graduates of the University of Southern California } \\
\text { Physician Assistant Program as controls }\end{array}$ \\
\hline Jablonski $^{22}$ & 2016 & Canada & $\begin{array}{l}\text { Quantitative } \\
\text { study }\end{array}$ & $\begin{array}{l}\text { Cross-sectional design for capturing } \\
\text { risk factors for the employment of } \\
\text { IMGs; } \\
\text { Cohort studies for the identification } \\
\text { of risk factors for securing residency } \\
\text { spots while utilizing the Access } \\
\text { Centre }\end{array}$ & $\begin{array}{l}\mathrm{N}=8,373 \\
\text { Non-English or French-speaking individuals }\end{array}$ \\
\hline Jones $^{33}$ & 2015 & $\begin{array}{l}\text { USA and } \\
\text { Canada }\end{array}$ & Commentary & $\mathrm{N} / \mathrm{A}$ & $\mathrm{N} / \mathrm{A}$ \\
\hline Liebich $^{34}$ & 2007 & $\begin{array}{l}\text { Australia, } \\
\text { but rele- } \\
\text { vant to } \\
\text { Canada }\end{array}$ & Report & $\mathrm{N} / \mathrm{A}$ & $\mathrm{N} / \mathrm{A}$ \\
\hline $\begin{array}{l}\text { Lim Consulting } \\
\text { Associates }^{12}\end{array}$ & 2013 & Canada & Report & Interviews & $\begin{array}{l}\text { Series of interviews with occupational contacts } \\
\text { (13 respondents), immigrant-serving organizations } \\
\text { (12 respondents), and related organizations and } \\
\text { internationally educated physicians ( } 13 \text { respondents) }\end{array}$ \\
\hline Magnus $^{35}$ & 2008 & $\begin{array}{l}\text { Ontario, } \\
\text { Canada }\end{array}$ & Commentary & $\mathrm{N} / \mathrm{A}$ & $\mathrm{N} / \mathrm{A}$ \\
\hline
\end{tabular}




\begin{tabular}{|c|c|c|c|c|c|}
\hline $\begin{array}{l}\text { Ministry of Health } \\
\text { and Long-Term } \\
\text { Care }^{21}\end{array}$ & 2012 & $\begin{array}{l}\text { Ontario, } \\
\text { Canada }\end{array}$ & Report & $\begin{array}{l}\text { Interviews; focus groups; surveys; } \\
\text { analysis of the administrative data }\end{array}$ & $\begin{array}{l}52 \text { PAs (32 IMG-stream) } \\
41 \text { supervising physicians } \\
33 \text { administrative representatives, including Clinical Direc- } \\
\text { tor/Manager/Other Administrative, Medical Administrator, } \\
\text { CNO/Professional Practice, CEO/Executive Director } \\
\text { Hospital Team survey: } 148 \\
\text { Hospital Team focus groups: } 13 \text { sites } \\
\text { Patient/Client satisfaction surveys: N/R } \\
\text { Hospital administrative data } \\
\text { CHC Purkinje administrative data } \\
\text { PEPA PA encounter reports } \\
\text { Physician Supervision time analysis }\end{array}$ \\
\hline $\begin{array}{l}\text { Neiterman, } \\
\text { Bourgeault \& } \\
\text { Covell }{ }^{30}\end{array}$ & 2017 & Canada & Qualitative study & Scoping review (Arksey \& O'Malley ${ }^{16}$ ) & 148 articles/reports \\
\hline $\begin{array}{l}\text { Smith \& } \\
\text { Fowkes }^{25}\end{array}$ & 1983 & USA & $\begin{array}{l}\text { Quantitative } \\
\text { study }\end{array}$ & $\begin{array}{l}\text { Surveys administered in person, by } \\
\text { telephone, and by mail }\end{array}$ & 736 unlicensed IMGs in California, USA \\
\hline Wick $^{24}$ & 2015 & USA & $\begin{array}{l}\text { Quantitative } \\
\text { study }\end{array}$ & $\begin{array}{l}\text { Descriptive statistics and chi-square } \\
\text { analysis or Fisher exact test to sum- } \\
\text { marize outcomes }\end{array}$ & $\begin{array}{l}\text { All IMGs (total } 39 \text { ) who completed the program through } \\
2013 \text { were included in the study; graduation year was col- } \\
\text { lapsed into two categories (1991-2005, } n=18 \text {; and 2006- } \\
2013, n=18 \text { ) }\end{array}$ \\
\hline
\end{tabular}

Note: $\mathrm{CEO}=$ chief executive officer $\mathrm{CHC}=$ community health center; $\mathrm{CNO}=$ College of Nurses of Ontario; IEN = Internationally Educated Nurse; IMG = international medical graduate; ITN =Internationally Trained Nurse; NP= nurse practitioner; N/A = not applicable; PA = physician assistant; PEPA = Physician-Employed Physician Assistant; US = United States; USA $=$ United States of America.

\section{Stage 5: Collating, summarizing, and reporting the results}

The final stage of a scoping review combines the findings from all eligible articles to deliver an evidence-based response to the original research question. Data were collected, synthesized, and presented using summary tables to inform the current state of evidence regarding the professional integration of IMGs through ACPs. The charted data were examined and compared to identify any patterns in the information on alternative careers for IMGs. The results of this process were further scrutinized to identify key themes. Table 4 details the key findings of each study pertaining to the professional integration of IMGs through ACPs. One reviewer (NC) completed the data analysis, but all authors reviewed the interpretation and reporting.

\section{Results}

\section{Literature search overview}

The systematic search of the three academic databases (MEDLINE, EMBASE, and Scopus) identified 953 articles, with an additional 86 articles found through searching the grey literature (Google Scholar). After removing duplicates, 809 articles were identified for the title and abstract screening. After reviewing the titles and abstracts, 320 articles were chosen for the full-text screening. The full-text screening revealed five eligible articles for the study. Through hand searching and snowballing the references of these articles, an additional 18 articles were identified. Finally, 23 studies were selected for this rapid scoping review (Figure 1).

\section{Study characteristics overview}

\section{Location}

Nine of 23 studies were conducted in the United States. Eleven studies were conducted in Canada, while one study focused on both Canada and the United States. Only one study was conducted in Australia; however, it described an ACP for IMGs that was tested in Canada.

\section{Type of research}

Most articles (11 of 23) within our eligible studies constituted reports written for different organizations. Eight studies were original research, four of which were quantitative, three were qualitative, and the remaining one used a mixed-method research approach. Two of the qualitative studies were scoping reviews; one of them included other internationally trained medical professionals (e.g., nurses, pharmacists, etc.) and none of them were focused on the integration of IMGs through ACPs. Three articles were commentaries written by researchers in academic journals, and one was a letter to the editor.

\section{Time-period}

Among our 23 articles of interest, 13 were published within the last 10 years (2010-2019). The remaining articles were published earlier.

\section{Methods and objectives of the studies}

The studies were very diverse in terms of their methodologies and objectives. Four of the original studies and organizational reports used surveys, four involved interviews, and one involved focus groups. Five studies analyzed data from different sources, including policy documents, ${ }^{20}$ administrative data, ${ }^{21,22}$ evaluation reports, ${ }^{23}$ and a graduation database ${ }^{24}$ of a potential ACP program for IMGs. These approaches were used to inquire about the potential of IMGs for an alternative career, ${ }^{25}$ evaluate IMGs preparedness for an ACP through tests, 26 capture the outcomes of a pilot ACP program for IMGs, ${ }^{21}$ review a support program, ${ }^{22}$ pilot a bridging program, ${ }^{23}$ evaluate an accredited program for ACPs, ${ }^{24}$ assess workshops, ${ }^{27}$ or to identify factors associated with professional integration. ${ }^{12,20,28}$ 


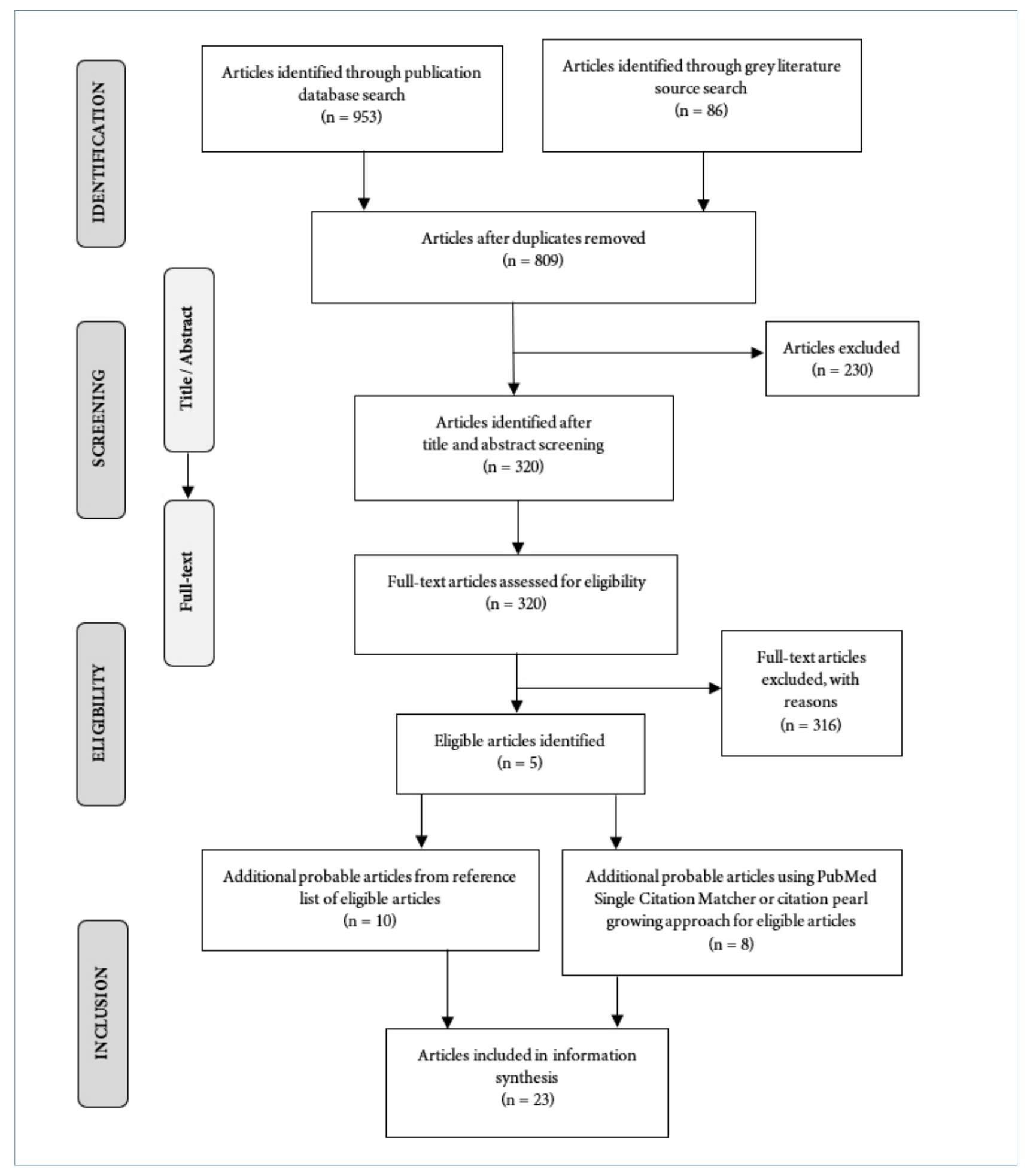

Figure 1. Study selection schematic 
Two scoping reviews attempted to find any gaps in the literature on professional integration of internationally trained health professionals. ${ }^{29,30}$ The remaining articles included reports, commentaries, and a 'letter to the editor'. ${ }^{31-36}$ The themes were related to experiences of IMGs working in $\mathrm{ACPs}^{31,36}$ and issues associated with the integration of IMGs through $\mathrm{ACPs}^{20,32,37,38}$ and described programs that enable IMGs to pursue an ACP. ${ }^{39,40}$

\section{Definition of alternative career}

We only found one study that provided a working definition for alternative careers for skilled immigrants in general and not specifically IMGs. It defined alternative careers as "those that immigrants pursue other than but related to the regulatory profession in which they were originally trained, that make use of and relate to an immigrant's skills and experience."12

\section{Benefits of an alternative career}

Several studies identified how alternative careers could be beneficial for both IMGs and stakeholders (Table 4). Stakeholders may include employers who have hiring capacity in those alternative careers, healthcare systems, governing bodies, and the community.

\section{Benefits for IMGs}

An alternative career provides IMGs who feel frustrated due to their loss of professional identity with an opportunity to regain a decent professional status and career satisfaction. ${ }^{25,27}$ Studies that reported on Physician Assistant (PA) positions for IMGs as an alternative career found that IMGs are interested in considering the profession, as it offers them a permanent career change instead of engaging in a lengthy and expensive process $^{36}$ and often not viable career ${ }^{25}$ through physician licensure. ${ }^{36}$ Some considered this an interim step toward licensure as a physician ${ }^{36}$ while gaining knowledge and experience of local healthcare systems,${ }^{31}$ obtaining Canadian medical experience, ${ }^{20}$ and maintaining their clinical proficiency. ${ }^{31}$ For some IMGs who did not obtain their medical degree from an institution approved in the International Medical Education Directory, an alternative career was the only option to consider. ${ }^{22}$

A report of an American program that fast-tracks IMGs to nursing noted that IMGs in the program reported that US nursing encompasses impressive levels of practice, often similar to those that many IMGs used to practice in their home countries. ${ }^{39}$ Many IMGs consider this path as an opportunity to re-enter the healthcare system. ${ }^{25}$ According to another study, female IMGs often give up on pursuing licensing and find alternative employment as midwives, nurses, or in alternative medicine, as these career paths are comparatively more certain than the physician licensure process. ${ }^{20}$

\section{Benefits for stakeholders}

One study showed that IMGs allowed to work as PAs provided an immediately available pool of primary healthcare providers for underserved populations who also may have shared their languages and cultures. ${ }^{36}$ This was reiterated in other studies where the need for primary care providers with culturally diverse backgrounds was apparent, particularly in places with a high number of immigrant populations, ${ }^{25}$ in rural and minority populations, ${ }^{38}$ or in underserved areas irrespective of the population demography. ${ }^{26,33}$ One study showed that the majority of the IMG-PA graduates from truncated programs worked in primary care and one-third practiced in medically underserved areas. ${ }^{24}$ Moreover, patients were happy to see a provider from the same cultural and linguistic background. ${ }^{24}$

A pilot project in Ontario, Canada employed IMGs in PA roles, as there were limited residency spots for IMGs, and they had shown a comparable level of PA competencies as articulated by the Canadian Association of Physician Assistants. ${ }^{34}$ One study pointed out that the number of applicants to educational programs for health professionals was decreasing, thereby resulting in a shortage of primary care providers, and these issues could immediately be compensated for ${ }^{31}$ by using IMGs in PA roles or clinical/surgical assistant roles in primary care settings. ${ }^{38}$

IMGs in nursing roles after completing a fast-track nursing program were highly preferred and welcomed by recruiters for several reasons. Firstly, they had the education and training of a physician and nurse practitioner. ${ }^{39}$ Secondly, it is far more cost-effective to employ nurse practitioners than fully licensed physicians in primary care. ${ }^{39,40}$

\section{Barriers to ACPs}

Across studies, a range of barriers faced by IMGs in their pursuit of alternative careers has been described. Some barriers arise at the individual level, while others are more systemic in nature. These barriers are discussed further below, and the results across the studies identified in this review are detailed in Table 4.

\section{Individual-level barriers}

\section{IMGs' lack of interest in ACPs}

Most of the IMGs in one study never considered looking for an alternative career to being a physician. ${ }^{27}$ Many contemplate switching their careers only after reaching a stumbling block in the pursuit of licensure. ${ }^{28}$ Studies also have shown that many IMGs are not interested in or committed to alternate professions and consider only those positions that may help them obtain Canadian clinical experience to facilitate their pursuit of physician licensure, e.g., PA or Clinical Assistant. ${ }^{33,36}$ 
Turin et al. Alternative career pathways for international medical graduates

Table 4. Barriers and facilitators encountered by IMGs in pursuing alternative careers

\begin{tabular}{|c|c|c|c|c|c|}
\hline Study & Year & $\begin{array}{l}\text { Benefits of the } \\
\text { alternative career } \\
\text { choice }\end{array}$ & Barriers & Facilitators & Recommendations \\
\hline $\begin{array}{l}\text { Alberta Interna- } \\
\text { tional Medical } \\
\text { Graduate } \\
\text { Association } \\
\end{array}$ & 2019 & $N / R$ & $\begin{array}{l}\text { Lack of professionals who } \\
\text { agree to take IMGs for job } \\
\text { shadowing or volunteering } \\
\text { Lack of IMG's persistence } \\
\text { in seeking employment }\end{array}$ & $\begin{array}{l}\text { One-to-one coaching } \\
\text { Developing professional pro- } \\
\text { files of the candidates } \\
\text { Introducing candidates to the } \\
\text { employers }\end{array}$ & $\begin{array}{l}\text { Career transition programs tailored to IMG } \\
\text { needs that identify, sharpen, and promote } \\
\text { the transferable skills of IMGs and connect } \\
\text { them with the employer can successfully } \\
\text { integrate IMGs into the labor market } \\
\text { through alternative careers and assist } \\
\text { IMGs to make timely, informed choices re- } \\
\text { garding their future career }\end{array}$ \\
\hline $\begin{array}{l}\text { American } \\
\text { Academy of } \\
\text { Physician } \\
\text { Assistants }^{32}\end{array}$ & 1993 & $\mathrm{~N} / \mathrm{R}$ & $\begin{array}{l}\text { Opposition by others, in- } \\
\text { cluding PA associations } \\
\text { and hospital associations }\end{array}$ & $\begin{array}{l}\text { Completing a full, accredited } \\
\text { PA program }\end{array}$ & $\begin{array}{l}\text { Allowing IMGs to be licensed as a PA } \\
\text { without a complete program was proved } \\
\text { ineffective and was opposed by PA } \\
\text { associations }\end{array}$ \\
\hline $\begin{array}{l}\text { Anderson \& } \\
\text { Gilliss }\end{array}$ & 1998 & $\mathrm{~N} / \mathrm{R}$ & $\begin{array}{l}\text { Lack of reading compre- } \\
\text { hension and command of } \\
\text { the English language }\end{array}$ & $N / R$ & $\begin{array}{l}\text { PA programs have attracted unlicensed } \\
\text { IMGs as applicants to their programs }\end{array}$ \\
\hline Bhimji1 & 2010 & $\begin{array}{l}\text { For IMGs: } \\
\text { To learn about the } \\
\text { healthcare system and } \\
\text { maintain some proficiency } \\
\text { For stakeholders: } \\
\text { Quick compensation of } \\
\text { shortage of physicians }\end{array}$ & $\begin{array}{l}\text { Inability to formulate a com- } \\
\text { plete treatment plan and to } \\
\text { communicate the plan to } \\
\text { the patient to the Canadian } \\
\text { standard } \\
\text { Lack of adequate training, } \\
\text { knowledge, and communi- } \\
\text { cation skills in the } \\
\text { healthcare-related work- } \\
\text { place safety practice } \\
\text { Funding } \\
\text { Limited leadership among } \\
\text { regulators and health au- } \\
\text { thorities }\end{array}$ & $\begin{array}{l}\text { Sponsored by organizations } \\
\text { like Medicentres Canada } \\
\text { Setting up a system with a cen- } \\
\text { tralized application process } \\
\text { and establishing a group of } \\
\text { qualified assessors and fund- } \\
\text { ing raised from potential em- } \\
\text { ployers and partially from the } \\
\text { government (proposed) }\end{array}$ & $\begin{array}{l}\text { A program under the supervision of } \\
\text { physicians for IMGs could work as an } \\
\text { alternative career for IMGs and a stepping- } \\
\text { stone toward licensure while compensating } \\
\text { for the physician shortage }\end{array}$ \\
\hline Bhuiyan ${ }^{23}$ & 2018 & $\begin{array}{l}\text { For IMGs: } \\
\text { An opportunity to utilize } \\
\text { their skills to facilitate their } \\
\text { integration into the } \\
\text { healthcare workforce } \\
\text { For stakeholders: } \\
\text { Enhance the provincial } \\
\text { and national economies } \\
\text { and build individual } \\
\text { capacity }\end{array}$ & $\mathrm{N} / \mathrm{R}$ & $N / R$ & $\begin{array}{l}\text { Bridging programs for internationally } \\
\text { trained doctors have the potential to create } \\
\text { positive individual and societal impacts } \\
\text { through capacity building for integration to } \\
\text { the non-licensed healthcare sector in } \\
\text { Canada }\end{array}$ \\
\hline $\begin{array}{l}\text { Blain, Fortin } \\
\& \text { Alvarez }{ }^{28}\end{array}$ & 2017 & & $N / R$ & $\begin{array}{l}\text { Taking an alternative path right } \\
\text { from the beginning or as soon } \\
\text { as they encounter a stumbling } \\
\text { block } \\
\text { Returning to school is a com- } \\
\text { mon strategy }\end{array}$ & $\begin{array}{l}\text { Taking alternative paths is a solitary } \\
\text { journey and most take them without } \\
\text { consulting formal resources }\end{array}$ \\
\hline $\begin{array}{l}\text { Bourgeault, } \\
\text { Neiterman, } \\
\text { Lebrun, Viers } \\
\text { \& Winkup }\end{array}$ & 2010 & $\begin{array}{l}\text { For IMGs: } \\
\text { Getting Canadian medical } \\
\text { experience } \\
\text { Female IMGs give up li- } \\
\text { censing and find alterna- } \\
\text { tive employment (as mid- } \\
\text { wives, nurses, or in } \\
\text { alternative medicine) due } \\
\text { to the uncertainty of the li- } \\
\text { censure process } \\
\text { For stakeholders: } \\
\text { N/R }\end{array}$ & $\begin{array}{l}\text { No help available for IMGs } \\
\text { to pursue alternate careers, } \\
\text { they do so on their own } \\
\text { No retraining programs for } \\
\text { IMGs to utilize } \\
\text { Professional networking } \\
\text { and proactivity are often } \\
\text { not enough to pursue an al- } \\
\text { ternate career }\end{array}$ & $\begin{array}{l}\text { Professional networking and } \\
\text { proactivity } \\
\text { Fate/luck }\end{array}$ & $\begin{array}{l}\text { To establish bridging programs that would } \\
\text { allow IMGs to practice in a health-related } \\
\text { field }\end{array}$ \\
\hline Cawley ${ }^{37}$ & 1994 & $N / R$ & $\begin{array}{l}\text { Opposition by others, in- } \\
\text { cluding PA associations } \\
\text { and hospital associations }\end{array}$ & $\begin{array}{l}\text { Completing a full, accredited } \\
\text { PA program }\end{array}$ & $\begin{array}{l}\text { Attempts to grant unlicensed IMGs the } \\
\text { opportunity of becoming a PA without } \\
\text { meeting standard requirements are often } \\
\text { failed by legislative efforts }\end{array}$ \\
\hline
\end{tabular}


IMGs unable to pass state medical licensing exams should not require a solution

\begin{tabular}{|c|c|c|c|c|}
\hline & & & & involving the PA profession \\
\hline $\begin{array}{l}\text { Covell, } \\
\text { Neiterman \& } \\
\text { Bourgeault }^{23}\end{array}$ & $2016 \mathrm{~N} / \mathrm{R}$ & $\begin{array}{l}\text { Starting work in "survival" } \\
\text { jobs causes difficulty for IE- } \\
\text { HPs to re-enter their de- } \\
\text { sired career in Canada } \\
\text { IEHPs' limited knowledge } \\
\text { in navigating professional } \\
\text { and other resources in the } \\
\text { host country }\end{array}$ & N/R & $\begin{array}{l}\text { To understand the importance of the devel- } \\
\text { opment of research and policy to employ } \\
\text { the unused human resources }\end{array}$ \\
\hline $\begin{array}{l}\text { Fasser \& } \\
\text { Smith }{ }^{38}\end{array}$ & $\begin{array}{l}1992 \text { For IMGs: } \\
\text { N/R } \\
\text { For stakeholders: } \\
\text { Diminishing numbers of } \\
\text { applicants to health pro- } \\
\text { fession educational pro- } \\
\text { grams and primary care } \\
\text { providers } \\
\text { To address the healthcare } \\
\text { needs of rural and minority } \\
\text { groups of the population }\end{array}$ & $\begin{array}{l}\text { Opposition of PA organiza- } \\
\text { tions against allowing unli- } \\
\text { censed IMGs to become } \\
\text { PAs based on a certain } \\
\text { score in the medical licens- } \\
\text { ing exams }\end{array}$ & Accredited course & $\begin{array}{l}\text { The issues of utilization of IMGs and the } \\
\text { risks associated with diminished control } \\
\text { over preparation of healthcare profession- } \\
\text { als need to be clearly articulated and con- } \\
\text { cerns of PA organizations addressed }\end{array}$ \\
\hline $\begin{array}{l}\text { Flowers \& } \\
\text { Olenick }{ }^{39}\end{array}$ & $\begin{array}{l}2014 \text { For IMGs: } \\
\text { US nursing is similar to } \\
\text { how IMGs practiced medi- } \\
\text { cine in their countries } \\
\text { Impressive level of prac- }\end{array}$ & N/R & $N / R$ & $\begin{array}{l}\text { IMGs with a Bachelor's or Master's in } \\
\text { Nursing can enhance patient access to } \\
\text { primary care in rural and urban areas. } \\
\text { Moreover, they are the perfect fit for the } \\
\text { socio-culturally and linguistically diverse } \\
\text { and underserved group of population. }\end{array}$ \\
\hline
\end{tabular}

Impressive level of prac-

tice by US nurse practi-

tioners

Opportunity to re-enter the healthcare

For stakeholders:

Recruiters actively seek

IMGs to hire, as they have

had physician, nurse, and

NP education and training

NPs are far more cost ef-

fective than physicians for primary care

\begin{tabular}{|c|c|c|c|c|}
\hline $\begin{array}{l}\text { Fowkes, } \\
\text { Cawley, } \\
\text { Herlihy \& } \\
\text { Cuadrado }^{36}\end{array}$ & $\begin{array}{l}1996 \text { For IMGs: } \\
\text { A permanent career } \\
\text { change due to lengthy and } \\
\text { expensive physician licen- } \\
\text { sure process } \\
\text { An interim step toward li- } \\
\text { censure as physicians } \\
\text { For stakeholders: } \\
\text { Immediately available pool } \\
\text { of potential healthcare } \\
\text { providers for underserved } \\
\text { populations that may } \\
\text { share their languages and } \\
\text { cultures }\end{array}$ & $\begin{array}{l}\text { Possible lack of socializa- } \\
\text { tion knowledge for PA role } \\
\text { and physician-PA relation- } \\
\text { ship } \\
\text { Lack of interest among } \\
\text { IMGs to become a PA } \\
\text { Lack of commitment of } \\
\text { IMGs to build a career as a } \\
\text { PA rather than using it as a } \\
\text { steppingstone } \\
\text { Language skills, behavioral } \\
\text { expectations, cultural is- } \\
\text { sues, or personal family } \\
\text { needs } \\
\text { Cost of developing exams } \\
\text { IMGs' lack of English-lan- } \\
\text { guage skills } \\
\text { Inability to verify past medi- } \\
\text { cal education } \\
\text { Fraud on applications } \\
\text { claiming prior medical edu- } \\
\text { cation } \\
\text { Lack of recent practice }\end{array}$ & $\begin{array}{l}\text { Preparatory programs appear } \\
\text { to lessen the barriers to PA } \\
\text { training }\end{array}$ & $\begin{array}{l}\text { IMGs are not equivalent to PAs without } \\
\text { specific training in accredited programs } \\
\text { Using public funds to offer preparatory } \\
\text { programs in order to add to the primary } \\
\text { care workforce may not be the wisest move }\end{array}$ \\
\hline $\begin{array}{l}\text { Grossman } \\
\& \text { Jorda } 40\end{array}$ & 2006 For IMGs: & English language skills & $\begin{array}{l}\text { Supporting programs for Eng- } \\
\text { lish language skills }\end{array}$ & $\begin{array}{l}\text { Unemployed or underemployed IMGs can } \\
\text { be a suitable source for meeting the }\end{array}$ \\
\hline
\end{tabular}


Turin et al. Alternative career pathways for international medical graduates

\begin{tabular}{|c|c|c|c|c|c|}
\hline & & $\begin{array}{l}\text { By choice when medical li- } \\
\text { censing was not possible } \\
\text { For stakeholders: } \\
\text { Fulfills the shortage of } \\
\text { RNs, especially from mi- } \\
\text { nority groups, and is cost- } \\
\text { effective }\end{array}$ & $\begin{array}{l}\text { Perception of their role and } \\
\text { position in healthcare is a } \\
\text { possible barrier }\end{array}$ & Socialization course & $\begin{array}{l}\text { demand of minority nurses in the US } \\
\text { through a fast-track program }\end{array}$ \\
\hline $\begin{array}{l}\text { Howard, } \\
\text { Garman \& } \\
\text { McCann }\end{array}$ & 1995 & $\begin{array}{l}\text { For IMGs: } \\
\text { N/R } \\
\text { For stakeholders: } \\
\text { An urgent need for more } \\
\text { medical practitioners in } \\
\text { underserved areas }\end{array}$ & $\begin{array}{l}\text { English as a second } \\
\text { language } \\
\text { Cultural and language } \\
\text { differences may have } \\
\text { affected patient } \\
\text { communication and } \\
\text { satisfaction } \\
\text { IMGs have a lower stand- } \\
\text { ard of knowledge and med- } \\
\text { ical skills than officially } \\
\text { trained PAs }\end{array}$ & $\begin{array}{l}\text { Further training on basic sci- } \\
\text { ence knowledge, clinical skills, } \\
\text { and awareness of the rights } \\
\text { and restrictions of the PA pro- } \\
\text { fession }\end{array}$ & $\begin{array}{l}\text { AAPA-recommended IMGs are required to } \\
\text { take a 12-15-month accredited PA training } \\
\text { program and subsequently pass the } \\
\text { national PA board exam and TOEFL to be } \\
\text { licensed as PAs }\end{array}$ \\
\hline Jablonski ${ }^{22}$ & 2012 & $\begin{array}{l}\text { For IMGs: } \\
\text { The only good option for } \\
\text { those whose medical de- } \\
\text { gree is not recognized in } \\
\text { the International Medical } \\
\text { Education Directory } \\
\text { IMGs' choices } \\
\text { For stakeholders: } \\
\text { N/R }\end{array}$ & $\mathrm{N} / \mathrm{R}$ & $N / R$ & $\begin{array}{l}\text { Most members do not use the resources of } \\
\text { the Access Centre } \\
\text { The very low success rate for alternative } \\
\text { career path }(0.4 \%)\end{array}$ \\
\hline Jones $^{33}$ & 2015 & $\begin{array}{l}\text { For stakeholders: } \\
\text { Using trained physicians } \\
\text { in a PA role addresses im- } \\
\text { mediate needs in } \\
\text { healthcare }\end{array}$ & $\begin{array}{l}\text { Very low } 15.6 \% \text { retention } \\
\text { rate of IMGs as PAs } \\
\text { IMGs without adequate } \\
\text { training, cultural adapta- } \\
\text { tion, and quality control in } \\
\text { PA role }\end{array}$ & $\begin{array}{l}\text { Providing structured educa- } \\
\text { tional and professional devel- } \\
\text { opment programs for PA role }\end{array}$ & $\begin{array}{l}\text { Without adequate formal education using } \\
\text { IMGs in PA role is a waste of time, energy, } \\
\text { and resources } \\
\text { Four months of training followed by hours } \\
\text { of evaluations could not adequately } \\
\text { prepare IMGs in PA roles and culture }\end{array}$ \\
\hline Liebich $^{34}$ & 2007 & $\begin{array}{l}\text { For IMGs: } \\
\text { N/R } \\
\text { For stakeholders: } \\
\text { Qualified IMGs could be a } \\
\text { potential resource as in } \\
\text { Ontario there were more } \\
\text { qualified IMGs than medi- } \\
\text { cal residency spots. } \\
\text { Their competencies are } \\
\text { comparable to formally } \\
\text { trained PAs. }\end{array}$ & $\begin{array}{l}\text { Concerns raised around } \\
\text { using IMGs as PAs }\end{array}$ & $N / R$ & $\begin{array}{l}\text { Idea of PAs is spreading outside the US } \\
\text { quickly and IMGs can play a role in this }\end{array}$ \\
\hline $\begin{array}{l}\text { Lim Consulting } \\
\text { Associates }^{12}\end{array}$ & 2013 & $\begin{array}{l}\text { For IMGs: } \\
\text { Not able to obtain license } \\
\text { For stakeholders: } \\
\text { Use of IMGs' transferable } \\
\text { skills }\end{array}$ & $\begin{array}{l}\text { Lack of employer aware- } \\
\text { ness of IEP abilities and } \\
\text { experience as a barrier to } \\
\text { finding employment } \\
\text { Language ability, cultural } \\
\text { competency, basic employ- } \\
\text { ment skills, unfamiliarity } \\
\text { with job search and the la- } \\
\text { bor market, lack of time } \\
\text { Lack of motivation } \\
\text { Lack of sustained funding } \\
\text { Insufficient training and } \\
\text { tools }\end{array}$ & $\begin{array}{l}\text { Accurate pre-arrival infor- } \\
\text { mation, counseling, training, } \\
\text { and guidance } \\
\text { Bridging programs } \\
\text { Employer linkages } \\
\text { Funding supports } \\
\text { Identifying skills transferability } \\
\text { and competency matching }\end{array}$ & $\begin{array}{l}\text { Physicians/dentists appear to have limited } \\
\text { alternative career options } \\
\text { Alternative careers should be deemed as a } \\
\text { parallel option to the career as a physician, } \\
\text { not as an option for failure } \\
\text { Partnerships between occupation-related } \\
\text { bodies (e.g., regulatory and certification au- } \\
\text { thorities and associations), employers, ed- } \\
\text { ucational institutions, service providers, } \\
\text { and government are required } \\
\text { The same challenges that hold back IEPs } \\
\text { from medical licensing prevent them to find } \\
\text { alternative careers (e.g., language and } \\
\text { communication skills) }\end{array}$ \\
\hline Magnus $^{35}$ & 2008 & $\begin{array}{l}\text { For IMGs: } \\
\text { A second career option for } \\
\text { IMGs } \\
\text { For stakeholders: } \\
\text { N/R }\end{array}$ & $N / R$ & $N / R$ & $\begin{array}{l}\text { Using IMGs as PAs in the future could } \\
\text { impact plans to develop a steady stream of } \\
\text { suitably trained individuals through } \\
\text { Canadian universities }\end{array}$ \\
\hline $\begin{array}{l}\text { Ministry of } \\
\text { Health and }\end{array}$ & 2012 & $N / R$ & $\begin{array}{l}\text { Lack of regulation of the PA } \\
\text { role }\end{array}$ & $\begin{array}{l}\text { PAs work with multiple Super- } \\
\text { vising Physicians to enable }\end{array}$ & $\begin{array}{l}\text { The impact of IMG-PAs was perceived } \\
\text { positively from their Supervising }\end{array}$ \\
\hline
\end{tabular}




\begin{tabular}{|c|c|c|c|c|}
\hline $\begin{array}{l}\text { Long-Term } \\
\text { Care } 21\end{array}$ & & $\begin{array}{l}\text { Timely development/ ad- } \\
\text { vancement of medical di- } \\
\text { rectives } \\
\text { Funding is a barrier to PA } \\
\text { role at hospital }\end{array}$ & $\begin{array}{l}\text { them to work across multiple } \\
\text { teams } \\
\text { Clarity around when a PA } \\
\text { could be called } \\
\text { Improved communication }\end{array}$ & $\begin{array}{l}\text { Physicians, patients, IMGs themselves, } \\
\text { and from analysis of administrative data } \\
\text { Low percentage ( } 41 \% \text { ) of IMG stream PAs' } \\
\text { interest on continuing to work as a PA }\end{array}$ \\
\hline $\begin{array}{l}\text { Neiterman, } \\
\text { Bourgeault } \\
\& \text { Covell }{ }^{30}\end{array}$ & 2017 N/R & $\begin{array}{l}\text { The recruiters of PA pro- } \\
\text { grams are often not wel- } \\
\text { coming to IMGs as they } \\
\text { think IMGs are only choos- } \\
\text { ing this training as a step- } \\
\text { ping stone }\end{array}$ & $\mathrm{N} / \mathrm{R}$ & $\begin{array}{l}\text { The literature on IMGs' integration to alter- } \\
\text { native careers are scarce. The existing } \\
\text { studies are more focused on what should } \\
\text { be done as opposed to what is being done. }\end{array}$ \\
\hline $\begin{array}{l}\text { Smith \& } \\
\text { Fowkes }^{25}\end{array}$ & $\begin{array}{l}1983 \text { For IMGs: } \\
\text { An alternative when con- } \\
\text { sidering physician licen- } \\
\text { sure in the US or Califor- } \\
\text { nia is not a viable } \\
\text { possibility } \\
\text { A way of employment and } \\
\text { job satisfaction } \\
\text { For stakeholders: } \\
\text { Need for primary care with } \\
\text { culturally diverse popula- } \\
\text { tions }\end{array}$ & $\begin{array}{l}\text { Experiencing discrimination } \\
\text { in non-physician profes- } \\
\text { sions both as IMGs and as } \\
\text { racial minorities } \\
\text { Many employers and oth- } \\
\text { ers in the medical profes- } \\
\text { sion do not believe that } \\
\text { IMGs working in non-physi- } \\
\text { cian health occupations are } \\
\text { beneficial to healthcare in } \\
\text { the US }\end{array}$ & $N / R$ & $\begin{array}{l}\text { Training and testing procedures are com- } \\
\text { pulsory for certification of IMGs as PAs }\end{array}$ \\
\hline Wick ${ }^{24}$ & $\begin{array}{l}2015 \text { For IMGs: } \\
\text { N/R } \\
\text { For stakeholders: } \\
\text { IMGs can to contribute to } \\
\text { the primary care work- } \\
\text { force, as well as specialty } \\
\text { practice }\end{array}$ & $\begin{array}{l}\text { IMGs may find it difficult to } \\
\text { be accepted by the rural } \\
\text { residents } \\
\text { It's unpredictable if the } \\
\text { IMGs will remain in the PA } \\
\text { profession }\end{array}$ & $\begin{array}{l}\text { Thorough applicant screening } \\
\text { process } \\
\text { Ensuring the following require- } \\
\text { ments before recruiting: } \\
\text { Minimum } 4,000 \text { hours of clini- } \\
\text { cal experience } \\
\text { Personal statement explaining } \\
\text { their role as PA professional } \\
\text { Supporting students with Eng- } \\
\text { lish as a second language }\end{array}$ & $\begin{array}{l}\text { Properly developed truncated PA programs } \\
\text { for IMGs can develop competent IMG-PAs } \\
\text { with better performing capability than for- } \\
\text { mally trained PAs } \\
\text { The majority of IMGs work in primary care } \\
\text { and about one-third in medically under- } \\
\text { served areas, which was the ultimate pur- } \\
\text { pose of such a program } \\
\text { Patients appreciated being able to see a } \\
\text { provider who shares their cultural and lin- } \\
\text { guistic background }\end{array}$ \\
\hline
\end{tabular}

Note: AAPA = American Academy of Physician Assistants; CAPA = Canadian Association of Physician Assistants; IEHP = internationally educated health professional; IEP = internationally educated physician; IMG = International Medical Graduate; ISO = immigrant serving organization; N/R = not recorded; NP = Nurse Practitioner; PA = Physician Assistant; RN $=$ Registered Nurse; TOEFL $=$ Test of English as a Foreign Language.

\section{Delayed start of alternative career search}

One study indicated that waiting too long to start looking for an alternative career may negatively impact the ability of IMGs to find alternative employment. ${ }^{28}$ According to that study, IMGs who joined a fast-track nursing program that prepares IMGs to work as a nurse practitioner attempted to obtain US medical residency for at least five years before considering alternative options. ${ }^{39}$ Many IMGs arrive in the host countries at a later stage of their life, have family responsibilities, and are not in a position to consider alternative careers that require 'starting over'. ${ }^{12}$

\section{Language ability and cultural competency}

Studies have indicated that IMGs may fail in alternative career roles due to language differences and a lack of cultural competency, ${ }^{36,40}$ particularly in non-physician healthcare roles that require patient communication and satisfaction, such as PA and Nurse Practitioner. ${ }^{26,31,41}$

\section{Unaware of the new work environment}

It was argued by one study that IMGs working as PAs displayed a lack of knowledge of their new roles as a PA and the respective professional behaviour. ${ }^{30,36}$ Similar doubt about
IMGs' perceptions of nurse practitioner roles and responsibilities was expressed in another study..$^{40}$ Uncertainty regarding IMGs' lack of knowledge about work environments and professional attitudes may inhibit recruiters from employing IMGs in alternative professions. ${ }^{12}$

\section{Financial barriers and job uncertainty}

Some alternative careers require further academic upgrading for IMGs, which can often be quite extensive and expensive. ${ }^{12}$ Moreover, a lack of certainty of securing employment after the investment of money and time in a program for alternative careers inhibits IMGs from pursuing alternative careers, particularly those requiring academic upgrading and investment of time and money. ${ }^{28}$

\section{Systemic barriers}

\section{Lack of information in alternative career options}

Immigrant IMGs may receive random pieces of information regarding alternative career options from immigrant-serving organizations (ISOs) that help skilled immigrants by providing professional information; however, there is often no structured source of information and resources available for them. ${ }^{12}$ Moreover, lack of knowledge about the labor market of the alternative careers, unfamiliarity with job search 
techniques, and lack of a professional network in the intended occupation impede the integration of IMGs into alternative careers. ${ }^{12}$

\section{Lack of systematic support}

One study reported that IMGs who found an alternative career had completed their professional journeys alone. ${ }^{28}$ They did not receive systematic support or consultation from experts. Their decisions were made on the basis of personal reflection and understanding the status of professional integration for IMGs in Canada. ${ }^{28}$

\section{Lack of opportunities for employer engagement}

Lack of local work experience for the respective jobs is an important barrier to IMGs' pursuit of alternative careers. ${ }^{12,27} \mathrm{~A}$ pilot workshop for IMGs bridging to alternative careers showed that managing a work placement, observership, internship, and volunteer opportunities is very difficult, without which securing a job is nearly impossible. ${ }^{27}$

\section{Lack of sustained funding}

A lack of sustained funding to ISOs that help skilled immigrants with their professional integration impedes the provision of their service. ${ }^{12}$ Funding is required to build partnerships with potential employers and other stakeholders and to develop bridging programs to prepare IMGs for the professions and connect them with potential employers. ${ }^{12}$

\section{Not recognizing transferable skill sets}

Recognizing IMGs' transferable skills is crucial to identifying and obtaining a suitable alternative career. ${ }^{12,27}$ In one study, IMGs reported that they had received extensive training in diagnosis and management of patients. Due to the specific nature of this training, employers and IMGs may not recognize the transferability of these skills to alternative careers. ${ }^{12}$ One respondent in that study suggested that IMGs' skills need to be systematically assessed in collaboration with potential recruiters and relevant experts. ${ }^{12}$

\section{Discrimination to IMGs in ACPs}

IMGs have reported facing discrimination due to working in non-physician professions, despite being trained as a physician, or being a member of a racial minority. ${ }^{25}$ Further, many employers believe IMGs working in a non-physician healthcare workforce is not beneficial to the overall healthcare system. ${ }^{25}$ They do not understand why an internationally qualified physician would seek employment in an alternate field, often one for which they are overqualified. ${ }^{36}$ Moreover, they are reluctant to hire IMGs, presuming that they are interested in using the position only as a stepping stone to their career goal. ${ }^{30}$

\section{Facilitators to ACPs}

Table 4 summarizes the facilitators reported across the studies identified in this review. The various facilitators are discussed further below.

\section{One-to-one consultation}

One-to-one coaching or consultation sessions may be beneficial to inform and prepare IMGs for their professional integration through ACPs. ${ }^{27}$ Such consultation is essential to assess their prior education and work experiences, as well as to identify transferable skills and help them make informed career choices. ${ }^{12,27}$ In addition, providing IMGs with a few highly salient successful case stories may help IMGs in transitioning to an alternative career. ${ }^{12}$

\section{Skill-building workshops}

One study demonstrated that workshops to prepare IMGs for particular alternative careers are useful. ${ }^{27}$ Moreover, including potential employers in the workshops helped increase their awareness regarding the potential of alternative careers as a way to professionally integrate IMGs. ${ }^{27}$

\section{Bridging programs with placements}

Developing bridging programs that help determine IMGs' transferable skills and build relevant new skills are essential for successful integration to alternative careers. ${ }^{27}$ However, one study indicated that IMGs preferred part-time programs that allow them to work and earn a living while upgrading themselves for alternative careers. ${ }^{12}$ Effective bridging programs should offer IMGs the opportunity of job shadowing, mentoring, and internships, as those are useful for both employers and IMGs. ${ }^{27}$

\section{Connecting IMGs with employers}

A pilot project in Alberta, Canada attempted to connect IMGs with potential employers by forwarding employers structured profiles of IMGs. ${ }^{27}$ This approach facilitated their employment, and the employers showed their interest in receiving additional similar referrals. ${ }^{27}$ Another study found that both IMGs and potential employers need to be informed about the potential requirements and relevant transferable skills of IMGs to better understand each other's employment needs. $^{12}$

\section{Alternative career roadmap and tools}

Key informants in one study reported that some organizations use their individual resources to help IMGs in their search for alternative careers. ${ }^{12}$ However, adopting a systematic approach and developing and applying a roadmap in collaboration with all stakeholders will make this more productive and practical. ${ }^{12}$ An assessment tool should be developed 
that takes into account prior education and experience and identifies gaps in the requirements for both employers and IMGs. $^{12}$

\section{Discussion}

In this rapid scoping review, we attempted to identify the current research and evidence-based understanding of alternative careers for IMGs. Although a few comprehensive studies were conducted, they indicate that ACPs are beneficial for both IMGs and the host country, especially where there is a good potential for utilizing IMGs' existing skillsets, such as non-physician health-related jobs. Studies showed that working as a physician is central to the individual identity of IMGs; however, when that goal becomes difficult to pursue due to the many barriers they encounter, they look for a career that is closely related to their profession, such as those in allied health and wellness professions. ${ }^{42}$ Despite the lower economic and professional outcomes from many of these careers, they opt for these alternatives as a way to remain in the health and wellness field. ${ }^{42}$ IMGs in health research, health informatics, and health management have the potential to enhance local and national economies by facilitating professional integration. ${ }^{23}$ Increasing the employability of skilled immigrants and creating capacities to contribute to society can also have a positive impact on both the individual IMGs and society. ${ }^{8}$ However, female IMGs may be more inclined to pursue alternative careers to establish their career more quickly, as the uncertainty of the physician licensure process undermines their family life. ${ }^{20}$

However, similar to the pathway to becoming a physician, IMGs are not spared from certain individual and systemic barriers in their pursuit of alternative careers. Individual barriers such as 'IMGs' lack of interest in ACPs', and 'Delayed start of alternative career search' indicate a lack of determination for alternative careers among some IMGs and a feeling of pushback toward the goal of becoming a practicing physician. 'Language ability and cultural competency' and 'Unaware of the new work environment' imply the need for socio-cultural and professional acculturation, respectively. 'Financial barriers and job uncertainty', on the other hand, demonstrates the vulnerability of these immigrant professionals and the struggles they face in the host country.

Reported systemic barriers such as 'Lack of information in alternative career options', 'Lack of systematic support', 'Lack of opportunities for employer engagement', and 'Lack of sustained funding' indicate the lack of systemic awareness and effort and action required to help IMGs integrate professionally through alternative careers. Other systemic barriers, namely 'Not recognizing transferable skill sets' and 'Discrimination to IMGs in ACPs', demonstrate the systemic reluctance and negative attitude toward IMGs' professional integration through alternative careers.

To find success in an alternative career, IMGs need to identify their hard and soft skills, knowledge, competencies (i.e., what they are good at) and aptitudes (i.e., what they can learn easily) required for the career. ${ }^{27,43}$ The studies in this review indicated that although IMGs have many transferable skills and aptitudes for learning, they generally need to refresh some of those skills, particularly within the context of the host country. They also require support and an opportunity to acquire new skills to be competitive candidates for those careers. 'One-to-one consultation', 'Skill-building workshops', and 'Bridging programs with placements' were proposed or piloted in some studies to facilitate this aspect of career development. Moreover, as an alternative career is a new field for the IMGs and there is a lack of awareness among employers about the potential of IMGs in alternative careers, helping IMGs to 'connect with employers' by supporting organizations through capacity development or professional development for IMGs/immigrants was found effective. Overall, 'an alternative career roadmap and tools' for both IMGs and the supporting organizations for alternative careers was urged.

The instrumental driver of an alternative career is being unable to obtain a position in the primary career. ${ }^{27,44}$ According to one study, only about a quarter $(24.7 \%)$ skilled immigrants work in their original profession, whereas more than half (54.7\%) of their Canadian-born counterparts work in the field for which they have been trained. ${ }^{45}$ Similar to IMGs, an alternative career is increasingly becoming a viable career pathway for the majority of other internationally trained health professionals, such as nurses, pharmacists, occupational therapists, midwives, medical laboratory technologists, and others ${ }^{20}$

\section{Implications for medical education}

Despite the potential of alternative careers, various factors, including being required to upgrade skills related to the alternative jobs, obtaining a professional license, obtaining certification or membership, and opportunities in the job market for those seeking alternative careers, are crucial. A pragmatic approach to alternative careers for IMGs through capacity building might be a worthy investment for host countries to help this under-appreciated group of immigrants contribute towards the health and wellness of the country, especially in underserved areas. ${ }^{40}$ Many studies reported that through meticulously developed bridging programs, IMGs could effectively be trained for different roles; however, these activities will benefit from proper engagement activities from their inception. Helping IMGs pursue ACPs instead of undertaking low-skilled jobs boosts IMGs' prospects of better integrating into the labor market and reduces the financial burden and economic loss caused by the underutilization and underemployment of skilled immigrants. ${ }^{46,47}$ Further, across the studies in our review, the IMG population was treated as a single homogeneous population, where in reality it is very heterogeneous. Factors such as cultural background, socioeconomic constraints in the new country, or time already spent in the new health system will be informative and need to be incorporated in our understanding of ACPs for IMGs. 


\section{Strengths and limitations}

This review has several strengths. The first is that it involved an extensive search strategy that included academic databases and grey literature. The conventional approach of conducting a rapid review is through a single database search; however, we searched three major academic databases with our research questions in mind. We also undertook a grey literature database search to help expand the scope of our search. However, this review also has some limitations we need to acknowledge. The inclusion criteria were quite broad; however, considering the fact that there was scarce research on ACPs of IMGs we deemed that as necessary to identify all available information on this topic. Further, in this review, we did not assess the quality of the literature, because of the diverse record types included in this review.

\section{Conclusions}

Through this rapid scoping review, we determined that the literature is scarce in the relatively new area of IMGs' professional integration through ACPs. Nevertheless, the existing studies indicate that these pathways have the potential to benefit both IMGs and the host country. Moreover, there is a myriad of barriers that need to be addressed to facilitate these undertakings, particularly the promotion of targeted bridging programs and skill development workshops for IMGs to help them pursue alternative careers. Helping IMGs navigate their pursuit of ACPs and the many barriers they might face in achieving their goals will increase the economic and societal integration of IMGs. As a next step, engagement with potential employers is required to create awareness among them, as well as to guide integration from employers' perspectives. Academics, support providers, industry stakeholders, and policymakers need to be engaged in this work to ensure uptake and impact.

\section{Conflict of Interest}

The authors declare that they have no conflict of interest.

\section{References}

1. Immigration, Refugees and Citizenship Canada. Immigration, refugees and citizenship canada departmental plan 2018-2019. 2018. [Cited 14 April 2020]; Available from: https://www.canada.ca/content/dam/ircc/migration/ircc/english/pdf/pub/dp-pm-2018-2019-eng.pdf.

2. Simich L, Beiser M, Stewart M, Mwakarimba E. Providing social support for immigrants and refugees in Canada: challenges and directions. J Immigr Health. 2005;7:259-268.

3. Ahmed S, Shommu N, Rumana N, Barron G, Wicklum S, Turin TC. Barriers to access of primary healthcare by immigrant populations in Canada: a literature review. J Immigr Minor Health. 2016;18:1522-1540.

4. Gérin-Lajoie D. The issue of diversity in the Canadian educational context. In: Gérin-Lajoie D, editor. Educators' discourses on student diversity in Canada: context, policy, and practice. Toronto: Canadian Scholars' Press; 2008. 5. Godley E. Foreign medical graduates face an uphill struggle for coveted Canadian internships. CMAJ. 1992;147:94-96.

6. National Center for Biotechnology Information. Foreign medical graduates. 1970. [Cited 14 April 2020]; Available from: https://www.ncbi.nlm.nih.gov/mesh/68005550.

7. Motala MI, Van Wyk JM. Experiences of foreign medical graduates (FMGs), international medical graduates (IMGs) and overseas trained 58 graduates (OTGs) on entering developing or middle-income countries like South Africa: a scoping review. Hum Resour Health. 2019;17: 7.

8. Thomson G, Cohl K. IMG selection. Independent review of access to postgraduate programs by international medical graduates in Ontario. 2011. [Cited 14 April 2020]; Available from: www.health.gov.on.ca/en/common/ministry/publications/reports/thomson/v1_thomson.pdf.

9. Young S. The problem of unmatched Canadian medical graduates: where are we now? The University of British Columbia Medical Journal. 2019; 10: 53-54.

10. Nedelman M. Why refugee doctors become taxi drivers. 2017. [Cited 14 April 2020]; Available from: https://www.cnn.com/2017/08/09/health/refugee-doctors-medical-training/index.html.

11. Bourgeault IL. Brain drain, brain gain and brain waste: programs aimed at integrating and retaining the best and the brightest in health care. Canadian Issues. 2007;4:96-99.

12. Lim Consulting Associates. Foreign qualifications recognition and alternative careers. 2013. [Cited 27 February 2020]; Available from: https://novascotia.ca/lae/rpllabourmobility/documents/alternativecareersresearchreport.pdf.

13. Khangura S, Konnyu K, Chman R, Grimshaw J, Moher D. Evidence summaries: the evolution of a rapid review approach. Syst Rev. 2012;1:10.

14. Tricco AC, Antony J, Zarin W, Strifler L, Ghassemi M, Ivory J, et al. A scoping review of rapid review methods. BMC Med. 2015;13:224.

15. Khangura S, Polisena J, Clifford TJ, Farrah K, Kamel C. Rapid review: an emerging approach to evidence synthesis in health technology assessment. Int J Technol Assess Health Care. 2014;30:20-27.

16. Arksey H, O'Malley L. Scoping studies: towards a methodological framework. International Journal of Social Research Methodology. 2005;8:19-32.

17. Tricco AC, Lillie E, Zarin W, O'Brien KK, Colquhoun H, Levac D, et al. PRISMA extension for scoping reviews (PRISMA-ScR): checklist and explanation. Ann Intern Med. 2018;169:467-473.

18. Haddaway NR, Collins AM, Coughlin D, Kirk S. The role of Google Scholar in evidence reviews and its applicability to grey literature searching. PLoS One. 2015; 10: e0138237.

19. Vaska M, Chowdhury MZI, Naidu J, Baig K, Turin TC. Exploring all that is grey in the health sciences: what is grey literature and how to use it for comprehensive knowledge synthesis. Journal of National Heart Foundation of Bangladesh. 2019;8:14-19.

20. Bourgeault IL, Neiterman E, Lebrun J, Viers K, Winkup J. Brain gain, drain \& waste: the experiences of internationally educated health professionals in Canada. 2010. [Cited 29 February 2020]; Available from: https://www.hhr-rhs.ca/en/?option=com_mtree\&task=att_down-

load\&link_id $=5474 \&$ cf_id $=68$.

21. Ministry of Health and Long-term Care. Ontario physician assistant implementation - report of the evaluation subcommittee. 2011. [Cited 29 February 2020]; Available from: https://capa-acam.ca/wp-content/uploads/2013/05/PA_Evaluation_Report_Final.pdf.

22. Jablonski JOD. Employment status and professional integration of IMGs in Ontario [Dissertation]. Ottawa, ON: University of Ottawa; 2012.

23. Bhuiyan SU. Ryerson University's internationally trained medical doctors bridging program: preliminary results from a pilot program. Journal of Professional, Continuing, and Online Education. 2018;3:1-10.

24. Wick KH. International medical graduates as physician assistants. JAAPA. 2015;28:43-46.

25. Smith MW, Fowkes VK. Unlicensed foreign medical graduates in California: social and demographic characteristics and progress toward licensure. Med Care. 1983;21:1168-1186.

26. Howard LW, Garman KA, McCann R-E. Another go at the experiment. Public Health Rep. 1995;110:668-673.

27. Alberta International Medical Graduate Association. Career transition program for IMGs: an exploration of alternative pathways into healthcare. Calgary, AB: Alberta International Medical Graduates Association; 2020. 28. Blain M-J, Fortin S, Alvarez F. Professional journeys of international medical graduates in Quebec: recognition, uphill battles, or career change. Journal of International Migration and Integration. 2017;18:223-247.

29. Covell CL, Neiterman E, Bourgeault IL. Scoping review about the professional integration of internationally educated health professionals. Hum Resour Health. 2016;14:38. 
30. Neiterman E, Bourgeault IL, Covell CL. What do we know and not know about the professional integration of international medical graduates (IMGs) in Canada? Healthc Policy. 2017;12:18-32.

31. Bhimji A. International medical graduates: The the Mmedicentres experience. Healthc Pap. 2010;10:46-49

32. Gara N. A challenge for the physician assistant profession: report of the AAPA Task Force on Unlicensed Medical Graduates. JAAPA. 1993;6:65-72.

33. Jones IW. Should international medical graduates work as physician assistants? JAAPA. 2015;28:8-10.

34. Liebich G. Physician assistants: utilisation in the United States and internationally - an update. 2007. [Cited 29 February 2020]; Available from: https://espace.library.uq.edu.au/view/UQ:34532.

35. Magnus B. Foreign-trained doctors dominate pilot project. CMAJ. 2008; $178: 1411$

36. Fowkes V, Cawley JF, Herlihy N, Cuadrado RR. Evaluating the potential of international medical graduates as physician assistants in primary care. Acad Med. 1996; 71: 886-892.

37. Cawley JF. IMGs seek to qualify as PAs in Maryland. Federation Bulletin. 1994;81:71-72.

38. Fasser CE, Smith QW. Foreign medical graduates as physician assistants: solution or threat. JAAPA. 1992;5:47-52.

39. Flowers $M$, Olenick M. Transitioning from physician to nurse practitioner. J Multidiscip Healthc. 2014;7:51-54.

40. Grossman D, Jorda ML. Transitioning foreign-educated physicians to nurses: the new Americans in nursing accelerated program. J Nurs Educ. 2008;47:544-551.

41. Anderson AL, Gilliss CL. Nurse practitioners, certified nurse midwives, and physician assistants in California. West J Med. 1998;168:437-444.

42. Shuval JT. The reconstruction of professional identity among immigrant physicians in three societies. J Immigr Health. 2000;2:191-202.

43. World Education Services (WES). Career pathways in nursing: using your foreign education in Canada. 2017. [Cited 3 October 2020]; Available from: https://knowledge.wes.org/GlobalTalentBridge-Eguide-Download-CanadaCareer-Pathways-Nursing.html

44. Scull S. Overseas-qualified professionals: the search for professional reentry and its perceived impact on settlement [Dissertation]. St. Lucia, QLD: The University of Queensland; 2016.

45. Augustine HJ. Employment match rates in the regulated professions: trends and policy implications. Canadian Public Policy. 2015;41:S28-S47.

46. Batalova J, Fix M, Bachmeier JD. Untapped talent: the costs of brain waste among highly skilled immigrants in the United States. 2016. [Cited 29 February 2020]; Available from: https://www.migrationpolicy.org/research/untapped-talent-costs-brain-waste-among-highly-skilled-immigrants-unitedstates.

47. Royal Bank of Canada. Immigrant labour market outcomes in Canada: the benefits of addressing wage and employment gaps. 2011. [Cited 21 February 2020]; Available from: http://www.rbc.com/newsroom/pdf/1219-2011immigration.pdf. 
Turin et al. - Alternative career pathways for international medical graduates

\section{Appendix 1.}

Preferred Reporting Items for Systematic Reviews and Meta-Analyses Extension for Scoping Reviews (PRISMA-ScR) checklist

\begin{tabular}{lllc}
\hline Section & Item & PRISMA-ScR Checklist Item & $\begin{array}{c}\text { Page(s) } \\
\text { Reported On }\end{array}$ \\
\hline Title & 1 & Identify the report as a scoping review. & Title page \\
\hline Title & & & $2-3$ \\
\hline Abstract & 2 & $\begin{array}{l}\text { Provide a structured summary that includes (as applicable): background, objectives, } \\
\text { eligibility criteria, sources of evidence, charting methods, results, and conclusions } \\
\text { that relate to the review questions and objectives. }\end{array}$ & 4 \\
\hline Introduction & 3 & $\begin{array}{l}\text { Describe the rationale for the review in the context of what is already known. Explain why } \\
\text { the review questions/objectives lend themselves to a scoping review approach. }\end{array}$ & 4 \\
\hline Rationale & 4 & $\begin{array}{l}\text { Provide an explicit statement of the questions and objectives being addressed with refer- } \\
\text { ence to their key elements (e.g., population or participants, concepts, and context) or other } \\
\text { relevant key elements used to conceptualize the review questions and/or objectives. }\end{array}$ & 5 \\
\hline Objectives & &
\end{tabular}

\begin{tabular}{|c|c|c|c|}
\hline \multicolumn{4}{|l|}{ Methods } \\
\hline $\begin{array}{l}\text { Protocol and } \\
\text { registration }\end{array}$ & 5 & $\begin{array}{l}\text { Indicate whether a review protocol exists; state if and where it can be accessed (e.g., a Web } \\
\text { address); and if available, provide registration information, including the registration } \\
\text { number. }\end{array}$ & N/A \\
\hline Eligibility criteria & 6 & $\begin{array}{l}\text { Specify characteristics of the sources of evidence used as eligibility criteria (e.g., years con- } \\
\text { sidered, language, and publication status), and provide a rationale. }\end{array}$ & 5-7 and Table 2 \\
\hline Information sources & 7 & $\begin{array}{l}\text { Describe all information sources in the search (e.g., databases with dates of coverage and } \\
\text { contact with authors to identify additional sources), as well as the date the most recent } \\
\text { search was executed. }\end{array}$ & $6-7$ \\
\hline Search & 8 & $\begin{array}{l}\text { Present the full electronic search strategy for at least } 1 \text { database, including any limits used, } \\
\text { such that it could be repeated. }\end{array}$ & Appendix 2 \\
\hline $\begin{array}{l}\text { Selection of sources of } \\
\text { evidence }\end{array}$ & 9 & $\begin{array}{l}\text { State the process for selecting sources of evidence (i.e., screening and eligibility) included } \\
\text { in the scoping review. }\end{array}$ & $7-8$ \\
\hline $\begin{array}{l}\text { Data charting } \\
\text { process }\end{array}$ & 10 & $\begin{array}{l}\text { Describe the methods of charting data from the included sources of evidence (e.g., cali- } \\
\text { brated forms or forms that have been tested by the team before their use, and whether data } \\
\text { charting was done independently or in duplicate) and any processes for obtaining and } \\
\text { confirming data from investigators. }\end{array}$ & 8 \\
\hline Data items & 11 & $\begin{array}{l}\text { List and define all variables for which data were sought and any assumptions and simplifi- } \\
\text { cations made. }\end{array}$ & $8-9$ \\
\hline $\begin{array}{l}\text { Critical appraisal of indi- } \\
\text { vidual sources of evi- } \\
\text { dence }\end{array}$ & 12 & $\begin{array}{l}\text { If done, provide a rationale for conducting a critical appraisal of included sources of evi- } \\
\text { dence; describe the methods used and how this information was used in any data synthesis } \\
\text { (if appropriate). }\end{array}$ & N/A \\
\hline Synthesis of results & 13 & Describe the methods of handling and summarizing the data that were charted. & $8-9$ \\
\hline \multicolumn{4}{|l|}{ Results } \\
\hline $\begin{array}{l}\text { Selection of sources of } \\
\text { evidence }\end{array}$ & 14 & $\begin{array}{l}\text { Give numbers of sources of evidence screened, assessed for eligibility, and included in the } \\
\text { review, with reasons for exclusions at each stage, ideally using a flow diagram. }\end{array}$ & $9-10$ \\
\hline $\begin{array}{l}\text { Characteristics of sources } \\
\text { of evidence }\end{array}$ & 15 & $\begin{array}{l}\text { For each source of evidence, present characteristics for which data were charted and pro- } \\
\text { vide the citations. }\end{array}$ & $9-10$ \\
\hline $\begin{array}{l}\text { Critical appraisal within } \\
\text { sources of } \\
\text { evidence }\end{array}$ & 16 & If done, present data on critical appraisal of included sources of evidence (see item 12). & N/A \\
\hline $\begin{array}{l}\text { Results of individual } \\
\text { sources of evidence }\end{array}$ & 17 & $\begin{array}{l}\text { For each included source of evidence, present the relevant data that were charted that re- } \\
\text { late to the review questions and objectives. }\end{array}$ & $10-11$ \\
\hline Synthesis of results & 18 & $\begin{array}{l}\text { Summarize and/or present the charting results as they relate to the review questions and } \\
\text { objectives. }\end{array}$ & $11-17$ \\
\hline
\end{tabular}




\begin{tabular}{|c|c|c|c|}
\hline \multicolumn{4}{|l|}{ Discussion } \\
\hline $\begin{array}{l}\text { Summary of } \\
\text { evidence }\end{array}$ & 19 & $\begin{array}{l}\text { Summarize the main results (including an overview of concepts, themes, and types of evi- } \\
\text { dence available), link to the review questions and objectives, and consider the relevance to } \\
\text { key groups. }\end{array}$ & $18-20$ \\
\hline Limitations & 20 & Discuss the limitations of the scoping review process. & 21 \\
\hline Conclusions & 21 & $\begin{array}{l}\text { Provide a general interpretation of the results with respect to the review questions and ob- } \\
\text { jectives, as well as potential implications and/or next steps. }\end{array}$ & $21-22$ \\
\hline \multicolumn{4}{|l|}{ Funding } \\
\hline Funding & 22 & $\begin{array}{l}\text { Describe sources of funding for the included sources of evidence, as well as sources of } \\
\text { funding for the scoping review. Describe the role of the funders of the scoping review. }\end{array}$ & $\mathrm{N} / \mathrm{A}$ \\
\hline
\end{tabular}


Turin et al. - Alternative career pathways for international medical graduates

\section{Appendix 2.}

Full electronic search strategy for MEDLINE and EMBASE

\begin{tabular}{|c|c|c|c|}
\hline No. & Search term (and operator) & $\begin{array}{c}\text { Results } \\
\text { (MEDLINE) }\end{array}$ & $\begin{array}{c}\text { Results } \\
\text { (EMBASE) }\end{array}$ \\
\hline 1 & exp Foreign Medical Graduates/ & 3433 & 247 \\
\hline 2 & Foreign medical graduate*.mp. & 3556 & 742 \\
\hline 3 & $\begin{array}{l}\text { (Foreign adj2 medical adj2 graduate }{ }^{*} \text {.mp. [mp=title, abstract, original title, name of substance word, } \\
\text { subject heading word, floating sub-heading word, keyword heading word, organism supplementary con- } \\
\text { cept word, protocol supplementary concept word, rare disease supplementary concept word, unique } \\
\text { identifier, synonyms] }\end{array}$ & 3597 & 825 \\
\hline 4 & $\begin{array}{l}\text { (international adj2 medical adj2 graduate }{ }^{\star} \text { ).mp. [mp=title, abstract, original title, name of substance } \\
\text { word, subject heading word, floating sub-heading word, keyword heading word, organism supplemen- } \\
\text { tary concept word, protocol supplementary concept word, rare disease supplementary concept word, } \\
\text { unique identifier, synonyms] }\end{array}$ & 894 & 1041 \\
\hline
\end{tabular}

5 (internationally adj2 trained adj2 doctor ${ }^{*}$ ).mp. [mp=title, abstract, original title, name of substance word, subject heading word, floating sub-heading word, keyword heading word, organism supplementary concept word, protocol supplementary concept word, rare disease supplementary concept word, unique identifier, synonyms]

6 (internationally adj2 trained adj2 physician ${ }^{\star}$ ).mp. [mp=title, abstract, original title, name of substance word, subject heading word, floating sub-heading word, keyword heading word, organism supplementary concept word, protocol supplementary concept word, rare disease supplementary concept word, unique identifier, synonyms]

7 (internationally adj2 trained adj2 medical graduate ${ }^{\star}$ ).mp. [mp=title, abstract, original title, name of substance word, subject heading word, floating sub-heading word, keyword heading word, organism supplementary concept word, protocol supplementary concept word, rare disease supplementary concept word, unique identifier, synonyms]

8 (internationally adj2 educated adj2 physician ${ }^{\star}$ ).mp. [mp=title, abstract, original title, name of substance word, subject heading word, floating sub-heading word, keyword heading word, organism supplementary concept word, protocol supplementary concept word, rare disease supplementary concept word, unique identifier, synonyms]

9 (internationally adj2 educated adj2 health adj2 professional ${ }^{*}$ ).mp. $[\mathrm{mp}=$ title, abstract, original title, name of substance word, subject heading word, floating sub-heading word, keyword heading word, organism supplementary concept word, protocol supplementary concept word, rare disease supplementary concept word, unique identifier, synonyms]

10 (internationally adj2 trained adj2 health adj2 professional ${ }^{\star}$ ).mp. $[\mathrm{mp}=$ title, abstract, original title, name of substance word, subject heading word, floating sub-heading word, keyword heading word, organism supplementary concept word, protocol supplementary concept word, rare disease supplementary concept word, unique identifier, synonyms]

11 (foreign adj2 trained adj2 doctor ${ }^{\star}$ ).mp. [mp=title, abstract, original title, name of substance word, subject heading word, floating sub-heading word, keyword heading word, organism supplementary concept word, protocol supplementary concept word, rare disease supplementary concept word, unique identifier, synonyms]

12 (foreign adj2 trained adj2 physician ${ }^{\star}$ ).mp. [ $\mathrm{mp}=$ title, abstract, original title, name of substance word, subject heading word, floating sub-heading word, keyword heading word, organism supplementary concept word, protocol supplementary concept word, rare disease supplementary concept word, unique identifier, synonyms] 
13 (foreign adj2 trained adj2 medical adj2 graduate ${ }^{\star}$ ).mp. [mp=title, abstract, original title, name of substance word, subject heading word, floating sub-heading word, keyword heading word, organism supplementary concept word, protocol supplementary concept word, rare disease supplementary concept word, unique identifier, synonyms]

14 (foreign adj2 educated adj2 physician $^{*}$ ).mp. [mp=title, abstract, original title, name of substance word, subject heading word, floating sub-heading word, keyword heading word, organism supplementary concept word, protocol supplementary concept word, rare disease supplementary concept word, unique identifier, synonyms]

15 (foreign adj2 educated adj2 health professional ${ }^{\star}$ ).mp. [mp=title, abstract, original title, name of substance word, subject heading word, floating sub-heading word, keyword heading word, organism supplementary concept word, protocol supplementary concept word, rare disease supplementary concept word, unique identifier, synonyms]

16 (overseas adj2 trained adj2 doctor ${ }^{\star}$ ).mp. [mp=title, abstract, original title, name of substance word, subject heading word, floating sub-heading word, keyword heading word, organism supplementary concept word, protocol supplementary concept word, rare disease supplementary concept word, unique identifier, synonyms]

17 (overseas adj2 trained adj2 health professional ${ }^{\star}$ ).mp. [mp=title, abstract, original title, name of substance word, subject heading word, floating sub-heading word, keyword heading word, organism supplementary concept word, protocol supplementary concept word, rare disease supplementary concept word, unique identifier, synonyms]

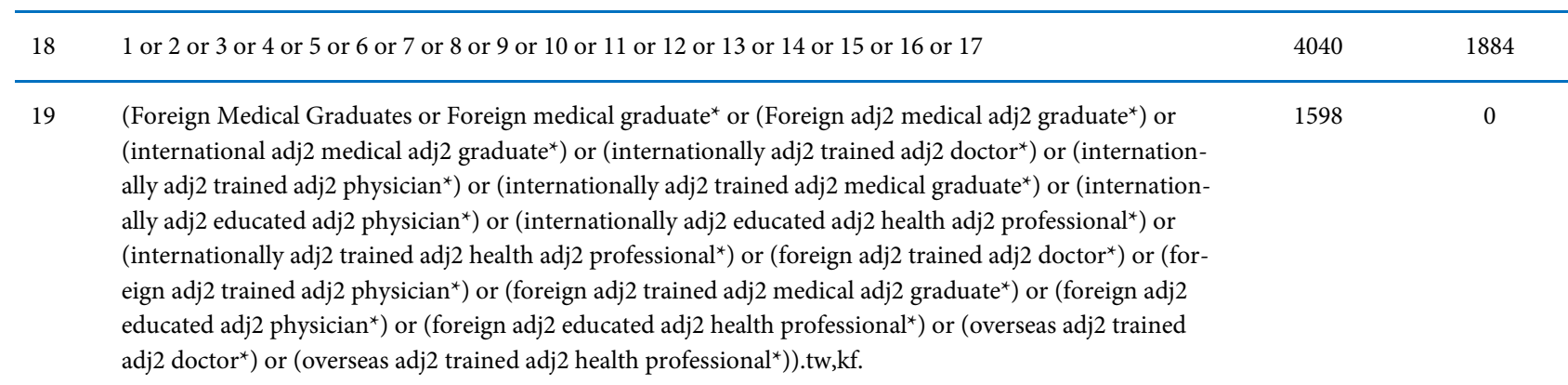

20 (Foreign Medical Graduates or Foreign medical graduate ${ }^{\star}$ or (Foreign adj2 medical adj2 graduate (Fo $^{*}$ (international adj2 medical adj2 graduate $^{\star}$ ) or (internationally adj2 trained adj2 doctor ${ }^{\star}$ ) or (internationally adj2 trained adj2 physician ${ }^{\star}$ ) or (internationally adj2 trained adj2 medical graduate ${ }^{\star}$ ) or (internationally adj2 educated adj2 physician ${ }^{\star}$ ) or (internationally adj2 educated adj2 health adj2 professional ${ }^{\star}$ ) or (internationally adj2 trained adj2 health adj2 professional ${ }^{\star}$ ) or (foreign adj2 trained adj2 doctor ${ }^{\star}$ ) or (foreign adj2 trained adj2 physician ${ }^{\star}$ ) or (foreign adj2 trained adj2 medical adj2 graduate ${ }^{\star}$ ) or (foreign adj2

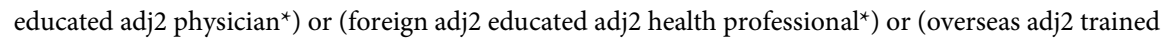
adj2 doctor $^{*}$ ) or (overseas adj2 trained adj2 health professional $\left.{ }^{*}\right)$ ).ti,ab.

\begin{tabular}{|c|c|c|c|}
\hline 21 & exp Career Choice/ or career.mp. & 55843 & 408593 \\
\hline 22 & $\begin{array}{l}\text { (profession }{ }^{*} \text { adj3 integrat }{ }^{\star} \text { ).mp. [mp=title, abstract, original title, name of substance word, subject head- } \\
\text { ing word, floating sub-heading word, keyword heading word, organism supplementary concept word, } \\
\text { protocol supplementary concept word, rare disease supplementary concept word, unique identifier, syn- } \\
\text { onyms] }\end{array}$ & 1141 & 1521 \\
\hline 23 & $\begin{array}{l}\text { (alternative adj3 career).mp. [mp=title, abstract, original title, name of substance word, subject heading } \\
\text { word, floating sub-heading word, keyword heading word, organism supplementary concept word, proto- } \\
\text { col supplementary concept word, rare disease supplementary concept word, unique identifier, synonyms] }\end{array}$ & 81 & 101 \\
\hline 24 & integrat* $^{*} \cdot \mathrm{mp}$. & 508251 & 612683 \\
\hline 25 & 21 or 22 or 23 or 24 & 562313 & 1002698 \\
\hline 26 & 18 and 25 & 426 & 327 \\
\hline
\end{tabular}

